\title{
CONSUMER PERCEPTION OF HEALTH PROPERTIES AND OF OTHER ATTRIBUTES OF BEEF AS DETERMINANTS OF CONSUMPTION AND PURCHASE DECISIONS
}

\author{
Krystyna Gutkowskal, Jacek Czarnecki², Dominika Głąbska³, Dominika Guzek', Agnieszka Batóg ${ }^{1}$ \\ ${ }^{1}$ Department of Organization and Consumption Economics, Faculty of Human Nutrition and Consumer Sciences, \\ Warsaw University of Life Sciences (WULS-SGGW), Warsaw, Poland \\ ${ }^{2}$ Nestlé Polska S.A., Warsaw, Poland \\ ${ }^{3}$ Department of Dietetics, Faculty of Human Nutrition and Consumer Sciences, Warsaw University of Life Sciences \\ (WULS-SGGW), Warsaw, Poland
}

\begin{abstract}
Background. Consumers may feel confused by receiving conflicting information about health-related aspects of beef. Therefore, it is invariably important to assess how consumers perceive the health benefits of beef.

Objective. The aim of the study was to assess the impact of consumer perception of beef values on consumer behavior towards this type of meat.

Material and methods. The study consisted of a survey conducted among residents of Świętokrzyskie voivodeship in the period February 2013 - September 2014. The research was conducted among 1004 consumers. The questions included in the questionnaire concerned habits associated with consumption of beef, as well as issues related to the process of purchasing decisions, and in particular the place and frequency of purchase of beef.

Results. It was found that the frequency of buying beef was also significantly dependent on consumer belief in the health attributes of beef. Consumers consuming beef for this reason more often indicated that they consume beef once a week and 2-3 times a month. On the other hand, consumers who did not eat beef because of its impact on health in which they believed, more often pointed to its occasional/ sporadic consumption, that is once a month and less often.

Conclusions. A significant percentage of consumers in the Świętokrzyskie voivodship misinterpret dietary recommendations and conclude that it is necessary to increase the consumption of beef due to medical reasons. Medical recommendations indicating the need to reduce meat consumption for a significant percentage of consumers from the Świętokrzyskie Voivodeship are of little importance and do not contribute to changing their eating behavior. Especially in the case of men, there is often a reluctance to change eating habits if it would involve the need to reduce the consumption of meat. There is a need to verify marketing messages and to carry out general nutrition education so that it is possible to actually reach consumers with information about the need to limit the consumption of meat products.
\end{abstract}

Key words: consumers, health benefits, beef, eating habits, marketing messages

\section{STRESZCZENIE}

Wprowadzenie. Konsumenci mogą czuć się zagubieni, otrzymując sprzeczne informacje na temat zdrowotnych aspektów wołowiny. Dlatego niezmiennie ważna jest ocena tego w jaki sposób konsumenci postrzegają walory zdrowotne mięsa wołowego. Cel badań. Celem badań była ocena wpływu konsumenckiej percepcji walorów wołowiny na zachowania konsumentów wobec tego rodzaju mięsa.

Material i metody. Badanie obejmowało ankiety przeprowadzone wśród mieszkańców województwa świętokrzyskiego w okresie luty 2013 - wrzesień 2014. Badania przeprowadzono wśród 1004 konsumentów. Zawarte w kwestionariuszu pytania dotyczyły m.in. zwyczajów spożywania mięsa wołowego, a także zagadnień związanych z procesem podejmowania decyzji zakupowych, a w szczególności miejsca i częstotliwości nabywania mięsa wołowego

Wyniki. Stwierdzono, że częstotliwość kupowania mięsa wołowego była istotnie statystycznie zależna od wiary konsumentów w zdrowotne atrybuty wołowiny. Konsumenci spożywający mięso wołowe z tego właśnie powodu częściej wskazywali, że spożywają wołowinę raz w tygodniu oraz 2-3 razy w miesiącu. Natomiast, konsumenci niespożywający wołowiny ze względu na jej wpływ na zdrowie w który wierzyli, wskazywali częściej na jej okazjonalne/sporadyczne spożywanie, a więc raz w miesiącu i rzadziej.

Corresponding author: Krystyna Gutkowska, Department of Organization and Consumption Economics, Faculty of Human Nutrition and Consumer Sciences, Warsaw University of Life Sciences (WULS-SGGW), 159c Nowoursynowska Str., 02-776 Warsaw, Poland, tel. +48 22 5937134, e-mail: krystyna_gutkowska@sggw.pl

CC Copyright by the National Institute of Public Health - National Institute of Hygiene 
Wnioski. Znaczny odsetek konsumentów z województwa świętokrzyskiego mylnie interpretuje zalecenia żywieniowe i wnioskuje o konieczności zwiększenia spożycia mięsa wołowego ze względów zdrowotnych. Zalecenia lekarskie wskazujące konieczność zmniejszenia spożycia mięsa dla znacznego odsetka konsumentów z województwa świętokrzyskiego mają małą ważność i nie przyczyniają się do zmiany ich zachowań żywieniowych. Szczególnie w przypadku mężczyzn częsta jest niechęć do zmiany nawyków żywieniowych, jeśli miałaby się ona wiązać z koniecznością zmniejszenia spożycia mięsa. Istnieje konieczność weryfikacji komunikatów marketingowych i takiego prowadzenia powszechnej edukacji żywieniowej, aby była możliwość faktycznego dotarcia do konsumentów z informacją o konieczności ograniczenia spożycia produktów mięsnych.

Słowa kluczowe: konsumenci, korzyści zdrowotne, wołowina, nawyki żywieniowe, komunikaty marketingowe

\section{INTRODUCTION}

In recent years, consumers are increasingly aware of the relationship between nutrition and health, which is reflected, among others, in the choices of food products and taking care of a properly balanced diet. Conscious consumer pays attention to what he chooses and reads the labels in the store. Thus, the health benefits of food become an important determinant of consumer purchasing decisions.

The positive effect of nutrients contained in beef, such as iron, zinc and copper, can be observed when the meat is eaten in reasonable amounts as part of a varied diet. However, due to the fact that in developed countries meat consumption is too high, excessive consumption of red meat is not recommended [23]. In the new Nutrition and Physical Activity Pyramid, the National Food and Nutrition Institute in Warsaw recommends a reduction in the consumption of meat and meat products, however, opinions on the nutritional qualities of meat are common among some consumers [5]. This may be due to the fact that nutritional value is often an element used in marketing communication [21].

On the other hand, the message about the nutritional value of red meat has recently been modified by various crises related not only to food safety (e.g., Bovine Spongiform Encephalopathy, BSE) [22], but also information on the negative impact of red meat consumption on health (e.g., cardiovascular diseases) [3].

Considering the above, consumers may feel confused by receiving conflicting information about health-related aspects of beef. Therefore, it is invariably important to assess how consumers perceive the health benefits of beef. The aim of the study was to assess the impact of consumer perception of beef values on consumer behavior towards this type of meat.

\section{MATERIAL AND METHODS}

The study consisted of a survey conducted among residents of Świętokrzyskie voivodeship in the period February 2013 - September 2014. A questionnaire was used that contained 49 questions (45 closed-ended questions and 4 open-ended questions). The research was conducted among 1206 consumers. The questions included in the questionnaire concerned habits associated with consumption of beef, as well as issues related to the process of purchasing decisions, and in particular the place and frequency of purchase of beef. The following were also included: consumer opinions on health risk at particular stages of delivering beef for consumption. In addition, the respondents mentioned the desirable characteristics of beef, sources from which they get information about this type of meat and their expectations in this regard.

After analyzing the completeness of filled questionnaires, those from 1004 respondents were qualified for final statistical analyzes. In the analysis of the test results, the chi ${ }^{2}$ test was used. The level of significance of $\mathrm{p} \leq 0.05$ was assumed. Statistica v. 12.0 PL statistical package from StatSoft, Inc. was used for the analysis of data.

\section{RESULTS}

The surveyed consumers were asked about the reasons for consumption of beef and most often they indicated the answer that it is tasty / they like it (47\%), and slightly fewer respondents (44\%) chose the answer about diversion of diet. More than every third respondent (39\%) stated that he eats beef because he considers it to be health-promoting product (Table 1).

Table 1. Declared reasons of beef consumption (multiple choice question)

\begin{tabular}{|l|c|}
\hline & $\begin{array}{c}\text { Frequency of a } \\
\text { specific answer [\%] }\end{array}$ \\
\hline It is tasty/ I like it & 47 \\
\hline For variety & 44 \\
\hline It is healthy & 39 \\
\hline It has universal value & 27 \\
\hline It better fits our dishes & 24 \\
\hline It is meat of a festive character & 16 \\
\hline It is filling & 15 \\
\hline It is easy to prepare & 13 \\
\hline It is my habit & 11 \\
\hline Due to health-related reasons & 10 \\
\hline Other & 4 \\
\hline
\end{tabular}


As a result of the analysis of the relationship between sociodemographic factors (gender, age, education, number of household members, number of household members under the age of 18 , occupation, monthly income and place of residence) and consumer declarations on the consumption of beef due to its potential health benefits, it was found that the age of the respondents and the level of education are factors that significantly differentiate respondents' responses. Among people declaring the consumption of beef primarily due to its health benefits, particularly high was percentage of consumers aged 26-30 years and 3640 years. It could be due to the fact that in this age group the importance of health in the hierarchy of values may be higher than in the case of younger respondents, and at the same time that knowledge of the actual recommendations regarding the need to reduce meat consumption may be lower than in the case of older consumers who may have diet related diseases.

Fifty percent of surveyed consumers who declared that health attributes are important for them were consumers with higher education and middle-level white-collar workers, while among those who do not eat beef because of this, significantly larger share were consumers with secondary education $(45 \%)$ and school and university students (34\%).

Analysis of association between reasons of beef consumption, associated with the nutritional habits or in-home consumption, and frequency of consumption is presented in Table 2 .

Table 2. Analysis of association between reasons of beef consumption, associated with the nutritional habits or in-home consumption, and frequency of consumption

\begin{tabular}{|c|c|c|c|c|c|c|}
\hline & & \multicolumn{2}{|c|}{ Yes } & \multicolumn{2}{|c|}{ No } & \multirow{2}{*}{$\mathrm{p}$-value } \\
\hline & & $\mathrm{N}$ & $\%$ & $\mathrm{~N}$ & $\%$ & \\
\hline \multirow{7}{*}{$\begin{array}{l}\text { Consumption of beef, because it } \\
\text { is a festive meat, eaten on special } \\
\text { occasions }\end{array}$} & Every day or almost every day & 1 & 2 & 4 & 1 & \multirow{7}{*}{0.001} \\
\hline & $4-6$ times a week & 0 & 0 & 23 & 6 & \\
\hline & 2 - 3 times a week & 1 & 2 & 29 & 8 & \\
\hline & Once a week & 7 & 11 & 89 & 24 & \\
\hline & 2 - 3 times a month & 11 & 17 & 67 & 18 & \\
\hline & Once a month & 11 & 17 & 69 & 18 & \\
\hline & Less often & 33 & 52 & 96 & 25 & \\
\hline \multirow{7}{*}{$\begin{array}{l}\text { Consumption of beef based on } \\
\text { habits/ eating behaviours }\end{array}$} & Every day or almost every day & 1 & 2 & 4 & 1 & \multirow{7}{*}{0.000} \\
\hline & 4 - 6 times a week & 8 & 19 & 15 & 4 & \\
\hline & 2 - 3 times a week & 4 & 10 & 26 & 7 & \\
\hline & Once a week & 11 & 26 & 85 & 21 & \\
\hline & 2 - 3 times a month & 9 & 21 & 69 & 17 & \\
\hline & Once a month & 6 & 14 & 74 & 19 & \\
\hline & Less often & 3 & 7 & 126 & 32 & \\
\hline \multirow{7}{*}{$\begin{array}{l}\text { Consumption of beef because it } \\
\text { is easy to prepare }\end{array}$} & Every day or almost every day & 4 & 7 & 1 & 0 & \multirow{7}{*}{0.000} \\
\hline & $4-6$ times a week & 7 & 12 & 16 & 4 & \\
\hline & 2 - 3 times a week & 10 & 17 & 20 & 5 & \\
\hline & Once a week & 13 & 22 & 83 & 22 & \\
\hline & 2 - 3 times a month & 9 & 15 & 69 & 18 & \\
\hline & Once a month & 8 & 13 & 72 & 19 & \\
\hline & Less often & 9 & 15 & 120 & 31 & \\
\hline
\end{tabular}

Consumers who think that beef has a festive character, and therefore it is advisable to eat it on special occasions, actually bought this type of meat less often than once a month, so they can be assumed as "special occasion consumers". On the other hand, consumers who did not declare a festive character of beef, more often indicated that they consume it at least once a week.

The frequency of buying beef was significantly dependent on the fact that consumers consume this product as a matter of routine or because of eating habits. Consumers consuming beef for this reason were more likely to buy it once a week.

The frequency of buying beef was also significantly dependent on consumers' belief that they were consuming this product, because it could easily make a tasty dish. Consumers consuming beef because of this reason bought and consumed beef more often than the average in the sample.

Analysis of association between reasons of beef consumption, associated with the perceived health or taste, and frequency of consumption is presented in Table 3. 
Table 3. Analysis of association between reasons of beef consumption, associated with the perceived health or taste, and frequency of consumption

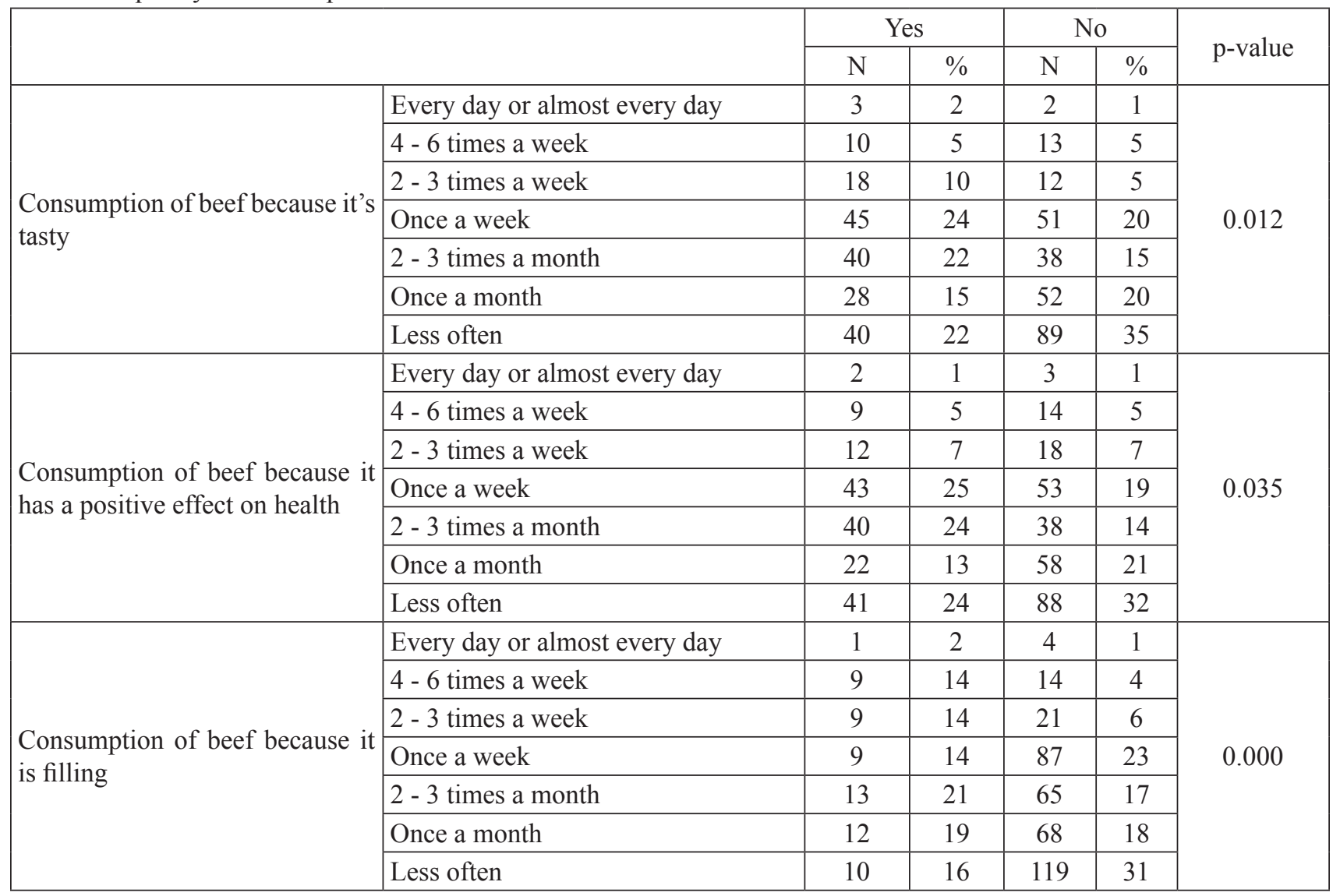

Table 4. Assessment of the significance of various sources of information or factors influencing consumers' decisions to buy beef (on a scale from 1 to 5 , where 1 - completely irrelevant feature and 5 - the most important feature)

\begin{tabular}{|c|c|c|c|c|c|c|c|c|c|c|}
\hline & \multicolumn{10}{|c|}{$\begin{array}{l}\text { Assessment of the significance of information sources or factors influencing } \\
\text { consumers' decisions to buy beef when making a purchase decision }\end{array}$} \\
\hline & \multicolumn{2}{|c|}{1} & \multicolumn{2}{|c|}{2} & \multicolumn{2}{|c|}{3} & \multicolumn{2}{|c|}{4} & \multicolumn{2}{|c|}{5} \\
\hline & $\mathrm{N}$ & $\%$ & $\mathrm{~N}$ & $\%$ & $\mathrm{~N}$ & $\%$ & $\mathrm{~N}$ & $\%$ & $\mathrm{~N}$ & $\%$ \\
\hline Medical advice & 189 & 29 & 76 & 12 & 128 & 20 & 97 & 15 & 154 & 24 \\
\hline Seller's recommendation & 154 & 25 & 139 & 23 & 164 & 27 & 91 & 15 & 64 & 10 \\
\hline Opinions of others, e.g. family, friends & 102 & 16 & 98 & 15 & 166 & 26 & 153 & 24 & 125 & 19 \\
\hline Press articles & 160 & 27 & 142 & 24 & 145 & 25 & 96 & 16 & 44 & 7 \\
\hline Advertising & 213 & 36 & 121 & 20 & 127 & 21 & 80 & 14 & 51 & 9 \\
\hline Exposition in the store & 134 & 22 & 117 & 20 & 172 & 29 & 104 & 17 & 69 & 12 \\
\hline Desire to eat a specific dish & 47 & 7 & 57 & 8 & 124 & 17 & 174 & 24 & 311 & 44 \\
\hline Own experience/wont & 64 & 10 & 83 & 13 & 137 & 21 & 149 & 23 & 228 & 34 \\
\hline Labelling information & 136 & 24 & 123 & 22 & 158 & 28 & 86 & 15 & 59 & 10 \\
\hline
\end{tabular}

It was found that consumers consuming beef due to taste preferences more often indicated the frequency of its purchase 2-3 times a week, once a week and 2-3 times a month. In turn, consumers who do not consume this type of meat because of its taste as the most important or important attribute, more often indicated its occasional consumption, that is once a month or even less frequently.

In addition it was found that the frequency of buying beef was also significantly dependent on consumer belief in the health attributes of beef. Consumers consuming beef for this reason more often indicated that they consume beef once a week and 2-3 times a month. On the other hand, consumers who did not eat beef because of its impact on health in which they believed, more often pointed to its occasional/ sporadic consumption, that is once a month and less often.

Conviction of consumers about energy value of beef (declaring that it is filling), probably prompted 
more frequent consumption of beef, and therefore at least 2-3 times a week, or several times a month (2-3 times a month). On the other hand, consumers who did not eat beef because of this, more often indicated the frequency of its purchase once a week and less frequently than once a month.

In the context of the aforementioned reflections on the source material concerning the impact of beef purchase determinants on the frequency of buying it, it can be stated that the hedonistic considerations influence the greater frequency of making decisions on purchasing beef, while less frequent consumption is influenced by the conviction of a festive character this kind of meat.

The analyzes also took into account the importance of various sources of information on beef for consumers' buying decisions. It was noted that the medical recommendation was slightly more often referred to as not very important information ( $41 \%$ of respondents indicated 1 and 2 on the scale of importance) than as important and very important $(15 \%$ and $24 \%$ respectively). It is puzzling that information about the hedonistic nature, and thus the desire to eat a specific dish (68\%) and previous experience and habits $(57 \%)$ turned out to be the most important (Table 4).

Table 5. Relationship between the gender of consumers and health reasons as a reason for reducing the level of consumption of beef (on a scale from 1 to 5 , where 1 - completely irrelevant feature and 5 - the most important feature)

\begin{tabular}{|c|c|c|c|c|c|c|}
\hline & \multicolumn{4}{|c|}{ Gender } & \multirow{3}{*}{ p-value } \\
\hline & & \multicolumn{2}{|c|}{ Female } & \multicolumn{2}{|c|}{ Male } & \\
\hline & & $\mathrm{N}$ & $\%$ & $\mathrm{~N}$ & $\%$ & \\
\hline \multirow{5}{*}{$\begin{array}{l}\text { Health } \\
\text { reasons }\end{array}$} & 1 & 30 & 34 & 96 & 45 & \multirow{5}{*}{0.044} \\
\hline & 2 & 19 & 22 & 32 & 15 & \\
\hline & 3 & 17 & 19 & 31 & 14 & \\
\hline & 4 & 18 & 20 & 29 & 14 & \\
\hline & 5 & 4 & 5 & 26 & 12 & \\
\hline
\end{tabular}

It was also noticed that gender significantly influenced the reduction of beef consumption due to health reasons. Both men and women rated (on a scale of 1 to 5) the importance of this reason most often at level 1 , however in the group of women the percentage of such assessments was significantly lower (34\%) than in the group of men ( $45 \%$ respectively) (Table $5)$. Thus, it can be assumed that men pay less attention to health reasons and are less likely to reduce the consumption of beef for this reason.

\section{DISCUSSION}

The results of many studies conducted among Polish consumers have proved that when purchasing food consumers pay special attention to the price of the product, personal preferences of them and their family members, taste values and the possibility of its impact on human health $[4,7,11]$. Other determinants affecting the process of food purchase, according to Karcz and Kędzior [9], are the quality of food and habits from the family home. Often the attention is also paid to the ease of preparing meals, the presence of additional substances, packaging and information on it, e.g. about the country of origin, nutritional value and expiration date $[12,19]$. However, recently, the impact on animal welfare during production has also become particularly important [15].

The significance of the price for the consumer as a factor conditioning the purchase of beef was confirmed a few years earlier in the study of PieszkoKlejnowska et al. [17]. Many other studies also point to the importance of price as a determinant playing an important role in the selection of not only meat, but also in the choice of food in general $[8,16,18]$. However, in the study of Moskalik and Wielicka [13], the price was mentioned as a factor that did not have a particularly significant impact on the selection of beef, while the expiration date was an important factor.

Other studies show that consumers are less and less willing to buy beef characterized by excess external fat, and its appearance is associated with a product that is not healthy [20]. Also for German consumers, the fat content in beef was an important feature taken into account when purchasing it. Subsequently, German consumers listed: aroma, tenderness, richness and colour [2].

Consumers from Portugal more often paid attention to the brand, colour, taste, juiciness and freshness of beef [1], while for Swedes, and especially for Swedish women, it was important to get information about the country of origin when purchasing this meat [6].

The results of the study of Kosicka-Gębska [10] have proved that concern about one's health is one of the most important factors affecting the decline in beef consumption among men, which may result from the fact that men preferring meat and beef more often can limit its consumption only with health reasons.

In the context of the studies indicated, the observed results can be described as quite typical for Poland and other developed countries. However, when analyzing them, it is necessary to pay attention to other factors that may affect the perception of meat products among consumers - such as differences in consumer expectations depending on their characteristics, which is often associated with the place of purchase of meat products [14].

Taking into account the frequent declarations shown in the own study, the selection of beef for health reasons and the reluctance to reduce consumption of this meat, even for health-related reasons and due to medical recommendations, there is a need to verify the 
media message. Marketing messages should be clearly formulated so that they do not create the misleading impression that consumers are encouraged to increase their consumption of beef. Special attention should be paid to male consumers, who were identified as especially prone to this problem.

\section{CONCLUSIONS}

1. A significant percentage of consumers in the Świętokrzyskie voivodship misinterpret dietary recommendations and conclude that it is necessary to increase the consumption of beef due to medical reasons.

2. Medical recommendations indicating the need to reduce meat consumption for a significant percentage of consumers from the Świętokrzyskie Voivodeship are of little importance and do not contribute to changing their eating behavior.

3. Especially in the case of men, there is often a reluctance to change eating habits if it would involve the need to reduce the consumption of meat.

4. There is a need to verify marketing messages and to carry out general nutrition education so that it is possible to actually reach consumers with information about the need to limit the consumption of meat products.

\section{Conflict of interest}

The authors declare no conflict of interest.

\section{REFERENCES}

1. Banović M., Grunert K.G., Barreira M.M., Fontes M.A.: Beef quality perception at the point of purchase: A study from Portugal. Food Qual Prefer 2009;20(4):335-342.

2. Becker T., Benner E., Glitsch K.: Consumer perception of fresh meat quality in Germany. $\mathrm{Br}$ Food J 2000;102(3):246-266.

3. Bronzato S., Durante A.: A Contemporary Review of the Relationship between Red Meat Consumption and Cardiovascular Risk. Int J Prev Med 2017;8:40.

4. Gutkowska K., Ozimek I.: Wybrane aspekty zachowań konsumentów na rynku żywności - kryteria zróżnicowania. [Selected aspects of consumer behavior on the food market - differentiation criteria]. Warszawa, Wyd. SGGW, 2005 (in Polish).

5. Gutkowska K., Żakowska-Biemans S., Kosicka-Gębska M., Sajdakowska M., Walkowiak M., Wierzbicki J., Jasiński C., Batóg A., Dziubińska J., Wronowski S.: Walory mięsa, ze szczególnym uwzględnieniem wołowiny, w opinii konsumentów w kontekście wyników badań jakościowych. [The qualities of meat, with particular emphasis on beef, in the opinion of consumers in the context of the results of qualitative research]. In. Gutkowska K., Sajdakowska M.:
Możliwości rozwoju rynku wołowiny w Polsce w kontekście zachowań konsumentów wobec mięsa odniesienia międzynarodowe. Warszawa, Wyd. SGGW, 2012 (in Polish).

6. Hoffmann R.: Country of origin - a consumer perception perspective of fresh meat. Br Food J 2000;1(3):211-222.

7. Jeżewska M.: Czynniki warunkujące zachowania żywieniowe we współczesnych gospodarstwach domowych. [Factors determining nutritional behavior in contemporary households]. Gospod. Dom. Kraju Świecie 1995;1:25 (in Polish).

8. Jomori M.M., da Costa Proenca R.P., Calvo M.C.M.: Determinantes de escolha alimentar. Rev Nutr 2008;21:1.

9. Karcz K., Kędzior Z.: Postawy konsumentów wobec produktów krajowych i zagranicznych. [Consumer attitudes towards domestic and foreign products]. Katowice, CBiE AE, 1999 (in Polish).

10. Kosicka-Gębska M.: Zachowania polskich konsumentów na rynku wołowiny. [Polish consumer behavior on the beef market]. Warszawa, Wyd. SGGW, 2013 (in Polish).

11. Kowrygo B.: Studium wpływu gospodarki rynkowej na sferę żywności i żywienia w Polsce. [Study of the impact of the market economy on the sphere of food and nutrition in Poland]. Warszawa, Wyd. SGGW, 2000 (in Polish).

12. Mazurek-Łopacińska K.: Badania marketingowe: podstawowe metody i obszary zastosowań. [Marketing research: basic methods and areas of application]. Wrocław, Wyd. Akademii Ekonomicznej im. Oskara Langego we Wrocławiu, 1999 (in Polish).

13. Moskalik B., Wielicka A.: Konsumpcja mięsa i produktów mięsnych. [Consumption of meat and meat products]. Rynek Wewnętrzny, 2006;238-234 (in Polish).

14. Olewnik-Mikołajewska A., Guzek D., Gtąbska D., Gutkowska, K.: Consumer behaviors toward novel functional and convenient meat products in Poland. J Sens Stud 2016;31:193-205. doi.org/10.1111/ joss. 12203 .

15. Olewnik-Mikołajewska A., Guzek D., Głąbska D., Sajdakowska M., Gutkowska K.: Fodder enrichment and sustaining animal well-being as methods of improving quality of animal-derived food products, in the aspect of consumer perception and acceptance. Anim Sci Pap Rep 2016;4:361-372.

16. Pieniak Z., Verbeke W., Vanhonacker F., Guerrero L., Hersleth M.: Association between traditional food consumption and motives for food choice in six European countries. Appetite 2009;53(1):101-108.

17. Pieszko-Klejnowska M., Stankiewicz M., Niedoszytko M., Kozanecka I., Łysiak-Szydłowska W.: Ocena sposobu odżywiania się gimnazjalnej młodzieży zamieszkującej wieś i miasto. [Evaluation of the diet of junior high school individuals living in the village and the city]. Pediatr Współ Gastroenterol Hepatol i Żyw Dziecka 2007;9(1):59-62 (in Polish).

18. Radziukiewicz M.: Zmiany wzorców konsumpcji polskich gospodarstw domowych. [Changes in 
consumption patterns of Polish households]. In: Janoś-Kresło M. ed. Gospodarstwa domowe XXI w. Konsumpcja. Jakość życia, Warszawa, SGH, 2012 (in Polish).

19. Sajdakowska M.: Etnocentryzm konsumencki-czynnik wpływający na decyzje nabywcze konsumentów na rynku żywności. [Consumer ethnocentrism - a factor influencing consumers' purchasing decisions on the food market]. Acta Sci Pol Technol Aliment 2003;1:177184 (in Polish).

20. Siriamornpun A., Li D., Wahlqvist M.L., Mann N.J., Received: 29.09.2018

Sinclair A.J.: Lean meat and heart health. Asia Pac J Accepted: 26.11.2018 Clin Nutr 2005;14(2):113-119.
21. Tapsell L.: Meat in the context of the whole diet: A social and cuisine perspective. Nutr Diet 2007;64:108-110.

22. Tilston C., Sear R., Neale R., Gregson K.: The effect of BSE: consumer perceptions and beef purchasing behaviour. Br Food J 1992;94(9):23-26.

23. Van Wezemael L., Verbeke W., de Barcellos M.D., Scholderer J., Perez-Cueto F.: Consumer perceptions of beef healthiness: results from a qualitative study in four European countries. BMC Public Health 2010;10:342. 